OPEN ACCESS

Citation: Habib K., Zulfiqar R., Khalid A.N. (2021) Additions to the lichen genus Rhizocarpon in Pakistan and their comparative analysis. Webbia. Journal of Plant Taxonomy and Geography 76(1): 123-134. doi: 10.36253/jopt-9889

Received: October 10, 2020

Accepted: January 2, 2021

Published: April 27, 2021

Copyright: @ 2021 Habib K., Zulfiqar R., Khalid A.N. This is an open access, peer-reviewed article published by Firenze University Press (http://www. fupress.com/webbia) and distributed under the terms of the Creative Commons Attribution License, which permits unrestricted use, distribution, and reproduction in any medium, provided the original author and source are credited.

Data Availability Statement: All relevant data are within the paper and its Supporting Information files.

Competing Interests: The Author(s) declare(s) no conflict of interest.

Editor: Riccardo M. Baldini

\section{Additions to the lichen genus Rhizocarpon in Pakistan and their comparative analysis}

\author{
Kamran Habib*, Rizwana Zulfiqar, Abdul Nasir Khalid \\ Fungal Biology and Systematics Lab, Department of Botany, University of the Punjab, \\ Lahore, Pakistan \\ *Corresponding author. E-mail: kamranhabiib@gmail.com
}

\begin{abstract}
As part of a comprehensive study of lichen diversity of northern areas of Pakistan using molecular and morphological approaches, we found four species of the genus Rhizocarpon. The analysis revealed two new species in the lichen biota of Pakistan namely, Rhizocarpon lavatum and Rhizocarpon petraeum, while the other two, Rhizocarpon disporum and Rhizocarpon geminatum are reported for the second time, from new localities. In comparison to literature information and GenBank sequences of the same taxa, variation in the morpho-anatomical features and nucleotide differences in the ITS marker of nrDNA have been documented. Descriptions and phylogenetic analysis of the taxa are given, along with information on ecology and distribution.
\end{abstract}

Keywords: Khyber Pakhtunkhwa, Lichens, Rhizocarpaceae, Taxonomy.

\section{INTRODUCTION}

Rhizocarpon Ramond ex DC. (Rhizocarpaceae, lichenized Ascomycota) is a large genus of lichenized or lichenicolous fungi, comprising approximately 200 currently accepted species (Davydov and Yakovchenko 2017). The members of the genus are usually recognized by a crustose thallus, a distinct prothallus, black lecideine apothecia, Rhizocarpon-type asci, and hyaline to brown, halonate ascospores that can be transversely septate or submuriform to muriform (Fletcher et al.2009; McCarthy and Elix 2014). The genus has a wide distribution throughout temperate to polar and alpine regions (Feuerer and Timdal 2004; Ihlen 2004; Kirk et al. 2008), occurring on siliceous or calcareous rocks (Moniri et al. 2009).

Ihlen and Ekman (2002) proposed a variety of infrageneric arrangement in Rhizocarpon. Previously suggested infrageneric arrangements based on presence or absence of the yellow substance rhizocarpic acid in the thallus or the septation of the ascospores are unnatural. Some species with grey or brown thallus may have evolved from a yellow ancestor. They have also justified that during the course of evolution, spore septation and colour, amyloidity of the thalline medulla, and the presence of stictic acid complex and rhizocarpic acid are changed multiple times (Ihlen and Ekman, 2002). The most widely-used classification is the one proposed by Thomson (1967), 
who divided the genus into taxa with a yellow thallus containing the pigment rhizocarpic acid (subgenus Rhizocarpon), and taxa with white, grey or brown thalli lacking rhizocarpic acid (subgenus Phaeothallus) (Ihlen 2004).

Only four species of this genus were so far known to occur in Pakistan, i.e., $R$. disporum (Nägeli ex Hepp) Müll.Arg., R. geminatum Körb. R. geographicum (L.) DC. (Ahmad 1965; Poelt 1961) and R. viridiatrum (Wulfen) Körb. (Ahmad 1965; Singh and Sinha 2010; Aptroot and Iqbal 2012). This study adds two more to the list of Rhizocarpon species of Pakistan.

\section{MATERIALS AND METHODS}

\section{Morphological and chemical studies}

The collections were made during a lichen survey of different sites of Azad Jammu and Kashmir, Pakistan, in 2019. Morphological characters were observed under a stereomicroscope (Meiji Techno, EMZ-5TR, Japan). Standard microscopy and spot tests (Hale 1979) were used for further identification. Measurements were made from free hand sections of apothecia mounted in water on glass slides. The sections were observed with a compound microscope (MX4300H, Meiji Techno, Japan).

\section{DNA extraction and PCR amplification}

We extracted fungal DNA from the thallus using a 2\% CTAB protocol (Gardes and Bruns 1993). Molecular data were generated for the internal transcribed spacer (ITS) region. The primer pair ITS1F (Gardes and Bruns 1993) and ITS4 (White et al.1990) was used to amplify the ITS region under the PCR conditions used by Khan et al. (2018). PCR products were visualized in a $1 \%$ agarose gel (Sambrook and Russell 2001) and sent to BGI Hong Kong, for sequencing.

\section{Phylogenetic analysis}

The ITS locus was amplified and sequenced for all specimens yielded fragments of about 700-800 bp each. The BioEdit sequence alignment editor was used to reassemble forward and reverse sequences (Hall 2005). The nucleotide sequence comparison was performed using the Basic Local Alignment Search Tool (BLAST) of the National Centre for Biotechnology Information (NCBI) (Altschul et al. 1990). The multiple sequence alignment was performed using MAFFT v.7 with all parameters set to default values (Katoh and Standley 2013). The phylogenetic tree was executed using software MEGA 10.0 (Kumar et al. 2018) with ML method based on Tamura 3-parameter model. Nodal support was evaluated using the "rapid bootstrapping" option with 1,000 replicates. For rooting purpose of the tree, Catolechia wahlenbergii (Ach.) Körb. (HQ650649) was selected as an out-group.

\section{Phylogeny}

Closest matching sequences were downloaded from GenBank for subsequent phylogenetic analysis. A total of 47 ITS rDNA sequences were analysed. The data matrix had 523 unambiguously aligned nucleotide positions among which 246 were constant, 271 variable, 213 parsimony-informative and 57 were singleton variants.

The Pakistani collections clustered in well supported groups (Figure 5). The sequence of Pakistani $R$. geminatum clustered with sequences from Norway (KY266908, AF483614), Svalbard (KP314320) and China (MK629880) of the same taxon. The affinity of these to the sister branch including $R$. bolanderi (Tuck.) Herre and $R$. disporum group which also contain the sequence of $R$. disporum from Pakistan. The Pakistani $R$. petraeum sequence clustered with $R$. petraeum (HQ605942) from Turkey to which the same taxon from Norway (AF483609) appeared as sister. The fourth sequence of Pakistani specimens clustered with $R$. lavatum reported from the same countries as those of $R$. petraeum.

\section{TAXONOMIC TREATMENT}

Rhizocarpon disporum (Nägeli ex Hepp) Müll. Arg., Revue mycol., Toulouse 1(4): 170. 1879 (Figure 1)

Thallus: Crustose-areolate, epilithic, effuse, dull, 13-14 cm across, pruinose. Areoles: immarginate, smooth, plane to convex, irregular, inflated, $0.3-1 \mathrm{~mm}$ in diameter. Colour: dark brown to greyish-black. Prothallus: distinct, black, prominent at margins or in between the areoles. Cortex: brown upper side, hyaline inside, paraplectenchymatous, $12-20 \mu \mathrm{m}$ thick, with epinecral layer $10-20 \mu \mathrm{m}$ thick, cells isodiametric, $8-10 \mu \mathrm{m}$ in diameter. Medulla: 200-300 $\mu \mathrm{m}$ thick, hyphae white, 2-4 $\mu \mathrm{m}$ wide. Algal layer: 85-125 $\mu \mathrm{m}$ thick, uneven, algae dispersed, mostly confined to upper portion of medulla, cells chlorococcoid, sphaerical to subsphaerical, $12-20 \mu \mathrm{m}$ in diameter.

Apothecia: frequent, present among or at the sides of areoles; Disc: black, adnate, pruinose, strongly con- 

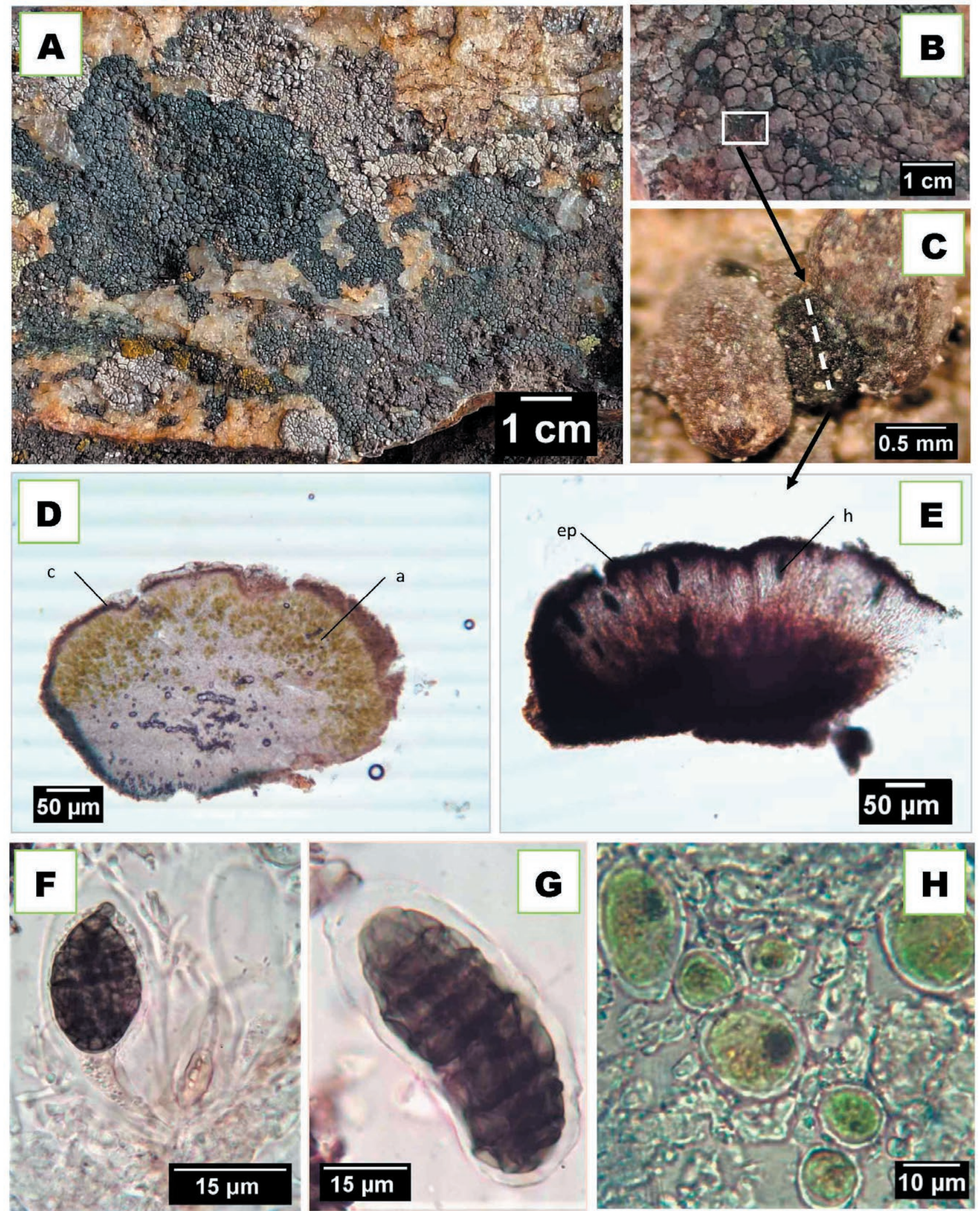

Figure 1. (A-H): Rhizocarpon disporum. A: Thallus; B: Areoles; C: Apothecium; D: Cross section of thallus (c: cortex; a: algal layer); E: Cross section of an apothecium (h: hymenium; ep: epihymenium); F: 1-spored asci; G: Ascospore; H: Chlorococcoid photobiont. 
vex, 0.3-0.8 $\mathrm{mm}$ in diameter. Margins: indistinct. Exciple: thick, distinct, black, 40-50 $\mu \mathrm{m}$ wide. Paraphyses: hyaline, septate, brown capitate, apex swollen, 3-4 $\mu \mathrm{m}$ wide. Epihymenium: blackish brown, 12-18 $\mu \mathrm{m}$ tall. Hymenium: hyaline, 80-125 $\mu \mathrm{m}$ tall. Hypothecium: dark brown, 40-60 $\mu \mathrm{m}$ tall. Asci: hyaline, clavate, 1-spored, 60-75 $\mu \mathrm{m} \times 30-35 \mu \mathrm{m}$. Ascospores: initially olive green becoming dark brown or blackish when mature, halonate, 3-5 $\mu \mathrm{m}$ thick, slightly curved, often tapered, muriform, broadly to narrowly ellipsoid, 40-55 $\mu \mathrm{m} \times$

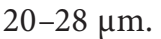

Chemistry: $\mathrm{K}-, \mathrm{C}-, \mathrm{KC}-$ : According to literature, it contains stictic acid and/or norstictic acid (Timdal \& Holtan-Hartwig 1988; Feuerer \& Timdal 2004; Galloway 2007) or to lack lichen substances (Timdal \& HoltanHartwig 1988).

\section{Material Examined}

PAKISTAN. Naran: Babusar top, $35^{\circ} 14^{\prime} \mathrm{N}, 74^{\circ} 04^{\prime} \mathrm{E}$; 4,173 m; moist temperate forest, on rock; July 21, 2019, A.N. Khalid \& K.Habib, (BAB-107), (LAH36713).

\section{Substrate and Ecology}

It was found in temperate climate at an altitude of 4,173 m.a.s.l., growing on rocks exposed to sun and rain. The region has hilly topography having maximum and minimum temperature of $35^{\circ} \mathrm{C}$ and $-8 \mathrm{C}$, respectively, and receive heavy snowfall in winter.

\section{Distribution}

It is known from Europe (Austria, Switzerland, Czech Republic, Estonia, France, Germany, Norway, Sweden, Spain) (Timdal \& Holtan-Hartwig 1988; Feuerer 1991; Golubkov and Matwiejuk 2009; https://www. gbif.org/); North America (Greenland, Canada, Mexico, US) (Feuerer \& Timdal 2004); Australia, New Zealand (McCarthy and Elix 2014; Galloway 2007), Antarctica (Øvstedal and Lewis Smith 2001) and Asia (Iran, Turkey, Pakistan) (Abbas et al. 2001; https://www.gbif.org/; Aptroot \& Iqbal 2012).

\section{Comments}

Rhizocarpon disporum is characterized by having grey to greyish black, or brown thallus, flat to convex or almost globose areoles, brown ascospores, and monosporous asci (Smith et al. 2009; Nash et al. 2004). The ITS sequence of Pakistani $R$. disporum is exactly similar to the same taxon from Siberia (MK629883, KY680774) indicating they are all the same species. The sequence of $R$. disporum from China (MK629882, MH979407, MH979408), Russia (KY680783) and USA (HQ650708) formed slightly separate branch from the Pakistani and Siberian $R$. disporum. Previously it has been reported from Gilgit-Baltistan, Pakistan (Poelt 1961). Our finding from Babusar Top is the second report of this taxon from Pakistan also represents a new record to Khyber Pakhtunkhwa.

Rhizocarpon geminatum Körb., Syst. lich. germ. (Breslau): 259. 1855 (Figure 2)

Thallus: crustose, epilithic, verrucose, areolate, determinate, $6 \mathrm{~cm}$ across, smooth, somewhat glossy, pruinose. Areoles: rounded to irregular, bullate, subglobose to rarely plane, $0.2-1 \mathrm{~mm}$ in diameter. Colour: dark brown to black when dry, dark reddish brown when wet. Prothallus: black, present among the areoles. Cortex: blackish, paraplectenchymatous, 12-25 $\mu \mathrm{m}$ thick, with an epinecral layer of 5-10 $\mu \mathrm{m}$ thick, cells rounded, 10-16 $\mu \mathrm{m}$ in diameter. Medulla: hyphae white, 3-4 $\mu \mathrm{m}$ wide. Algal layer: algae evenly distributed throughout thallus, cells chlorococcoid, sphaerical to subsphaerical, 15-20 $\mu \mathrm{m}$ in diameter.

Apothecia: frequent, present between or at the side of areole. Disc: black, smooth, plane to strongly convex, glossy, pruinose, $0.2-0.6 \mathrm{~mm}$ in diameter. Margins: indistinct. Exciple: thick, distinct, peripherally black, grey to brown inside, prosoplectenchymatous, 40-55 $\mu \mathrm{m}$ wide. Paraphyses: hyaline, septate, apex swollen, 3-4 $\mu \mathrm{m}$ in width. Epihymenium: dark brown, 12-20 $\mu \mathrm{m}$ tall. Hymenium: hyaline, 130-200 $\mu \mathrm{m}$ tall. Hypothecium: brown, 75-96 $\mu \mathrm{m}$ tall. Asci: hyaline, 2-spored, 55-65 $\mu \mathrm{m} \times 14-25 \mu \mathrm{m}$. Ascospores: pale green initially, becoming dark brown, broadly to narrowly ellipsoid, halonate, muriform, 35-50 $\mu \mathrm{m} \times 24-32 \mu \mathrm{m}$.

Chemistry: K-, C-, KC-: Stictic acid and norstictic acid has been reported or to lack lichen substances according to literature, not examined in the present material (Feuerer 1991; Timdal \& Holtan-Hartwig 1988; Øvstedal \& Lewis Smith 2001; Feuerer \& Timdal 2004; Fletcher et al. 2009; Galloway 2007). McCarthy \& Elix (2014) have observed a new chemotype containing only bourgeanic acid as well as the chemotypes with stictic acid and its satellite compounds (constictic, cryptostictic and peristictic acids) or norstictic acid, taccessory bourgeanic acid.

\section{Material Examined}

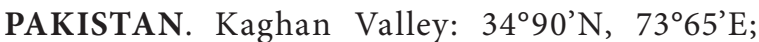
2,409 m; temperate climate, on rocks; July 21, 2019, A.N. Khalid \& K. Habib, (BAB-108), (LAH36714). 

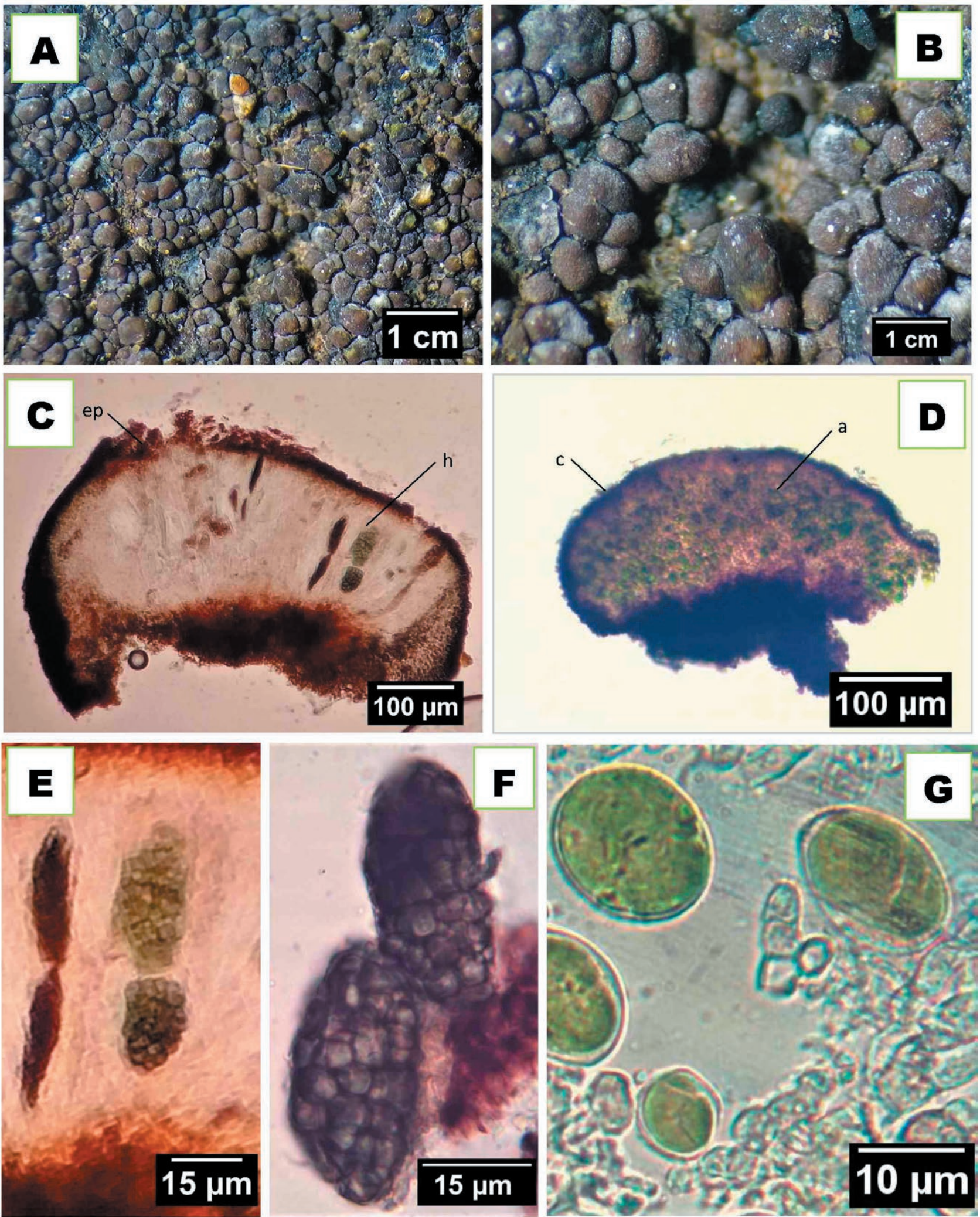

Figure 2. (A-G): Rhizocarpon geminatum. A\&B: showing verrucose thallus; C: Cross section of an apothecium (h: hymenium; ep: epihymenium); D: Cross section of thallus (c: cortex; a: algal layer); E: Two spores per ascus; F: Ascospores; G: Chlorococcoid photobiont. 


\section{Substrate and Ecology}

It was found at an altitude of 2,509 m.a.s.l., growing on sun and rain exposed rocks in partially forested area. The region has hilly topography with mean maximum and minimum temperature: $21.5^{\circ} \mathrm{C}$ and $-2^{\circ} \mathrm{C}$ respectively, and receive heavy snowfall in winter.

\section{Distribution}

The species is known from North America, (Nash et al. 2004), Europe (Clauzade and Roux 1985, Timdal and Holtan-Hartwig 1988, Feuerer 1991, Feuerer and Timdal 2004; Fletcher et al. 2009), Antarctica (Øvstedal and Smith 2001), Australia (McCarthy and Elix 2014) and Asia (Ahmad 1965, https://www.gbif.org/).

\section{Comments}

Rhizocarpon geminatum is characterized by its dark grey convex-areolate thallus, a non-amyloid medulla, innate apothecia, moderately large ascospores, 2-spored asci and a variable chemistry (McCarthy and Elix 2014). Morphologically, it is close to $R$. grande but that species has 8-spored asci, smaller ascospores, and a thallus containing gyrophoric acid (C+ red) (Smith et al. 2009).

Phylogenetically, there are four nucleotide difference at site 77, 82, 124 and 504 between Pakistani $R$. geminatum and R. geminatum (KP314320, MK629880, KY266908) from Svalbard, China and Norway respectively, but similar at the same position for $R$. geminatum reported from Norway (AF483614). Previously, it has been reported from Swat, Pakistan (Ahmad 1965). Our finding from Naran represents a new record for this region and also represents its wide distribution in Pakistan.

Rhizocarpon lavatum (Fr.) Hazsl., Magyar Birodalom Zuzmó-Flórájá: 206. 1884 (Figure 3)

Thallus: crustose, epilithic, rimose-areolate, deeply cracked, $8 \mathrm{~cm}$ across, dull. Areoles: smooth, epruinose to slightly pruinose, polygonal to elongated, flat to weakly convex, initially contiguous becoming discrete, $0.4-1.2$ $\mathrm{mm}$ in diameter, $0.2-0.7 \mathrm{~mm}$ thick, replicating by division. Colour: rusty brown to dark brown when dry, pale reddish brown when wet. Prothallus: absent. Cortex: two layered, upper layer blackish, lower layer hyaline, paraplectenchymatous, 25-33 $\mu \mathrm{m}$ thick, with isodiametric cortical cells, $12-15 \mu \mathrm{m}$ in diameter. Medulla: hyphae white, 3-4 $\mu \mathrm{m}$ wide; Algal layer: $74-93 \mu \mathrm{m}$ thick, continuous, even, corresponding with areole size, photobiont chlorococcoid, cells globose to subglobose, 10-20 $\mu \mathrm{m}$ in diameter.
Apothecia: frequent, appear between areoles. Disc: brown to black, flat to convex, rounded, rarely irregular, up to $1.2 \mathrm{~mm}$ in diameter, dull, slight pruinose. Margins: concolorous to disc, persistent, distinct, continuous, slight glossy, more prominent in younger ones. Exciple: peripherally blackish brown, inside hyaline, poorly differentiated from hypothecium. Paraphyses: hyaline, septate, apex swollen, 2-3 $\mu \mathrm{m}$ wide. Epihymenium: reddish brown, 30-40 $\mu \mathrm{m}$ high. Hymenium: hyaline, 130-155 $\mu \mathrm{m}$ tall. Hypothecium: dark brown, $25-35 \mu \mathrm{m}$ tall. Asci: hyaline, 8-spored, 70-95 $\mu \mathrm{m} \times 15-22 \mu \mathrm{m}$. Ascospores: narrowly ellipsoid to ellipsoid, halonate, hyaline, eumuriform, 8-17cells in optical view, $24-32 \mu \mathrm{m} \times 8-12 \mu \mathrm{m}$.

Chemistry: K-, C-, KC-: According to literature, this species lacks lichen substances (Feuerer 1991; Ihlen 2004; Galloway 2007; Fletcher et al. 2009; Joshi et al. 2010; Timdal and Holtan-Hartwig 1988).

\section{Material Examined}

PAKISTAN. Azad Jammu \& Kashmir: Neelam Valley; Kel, $34^{\circ} 50^{\prime} \mathrm{N}, 74^{\circ} 22^{\prime} \mathrm{E}$; $2,097 \mathrm{~m}$; on rock; July 12, 2019, A.N. Khalid \& K. Habib, (KL-01), (LAH36711).

\section{Substrate and Ecology}

It was found in Himalayan temperate forest, growing on sun and rain exposed rocks at an altitude of 2,097 m.a.s.l. The mean maximum and minimum temperature of the area is $28^{\circ} \mathrm{C}$ and $-2^{\circ} \mathrm{C}$, respectively, and receive an average annual rainfall of $749 \mathrm{~mm}$. The dominant tree species around were Cedrus deodara (Roxb. ex Lambert) G.Don, Pinus wallichiana A.B. Jacks., Picea smithiana Boiss., Abies pindrow Royle.

\section{Distribution}

The species is reported from North and South America (Feuerer \& Timdal 2004; Nash et al. 2004), Europe (Clauzade and Roux 1985; Fletcher et al. 2009), Australia, New Zealand (Galloway 2007; McCarthy and Elix 2014), Antarctica (Øvstedal and Smith 2001), and Asia (https://www.gbif.org/; Ahmad 1965).

\section{Comments}

Rhizocarpon lavatum is recognized by its large apothecia with thick margin, long narrow ascospores with many cells (15-24), and rimose thin thallus lacking secondary substances (Ihlen, 2004; Wang et al. 2015). Morphologically, $R$. lavatum is close to Rhizocarpon timdalii but the later can be distinguished by strongly convex areoles and apothecia. Rhizocarpon reductum is another most similar species to $R$. lavatum, but the presence of stictic acid makes it distinct. Apart from that charac- 

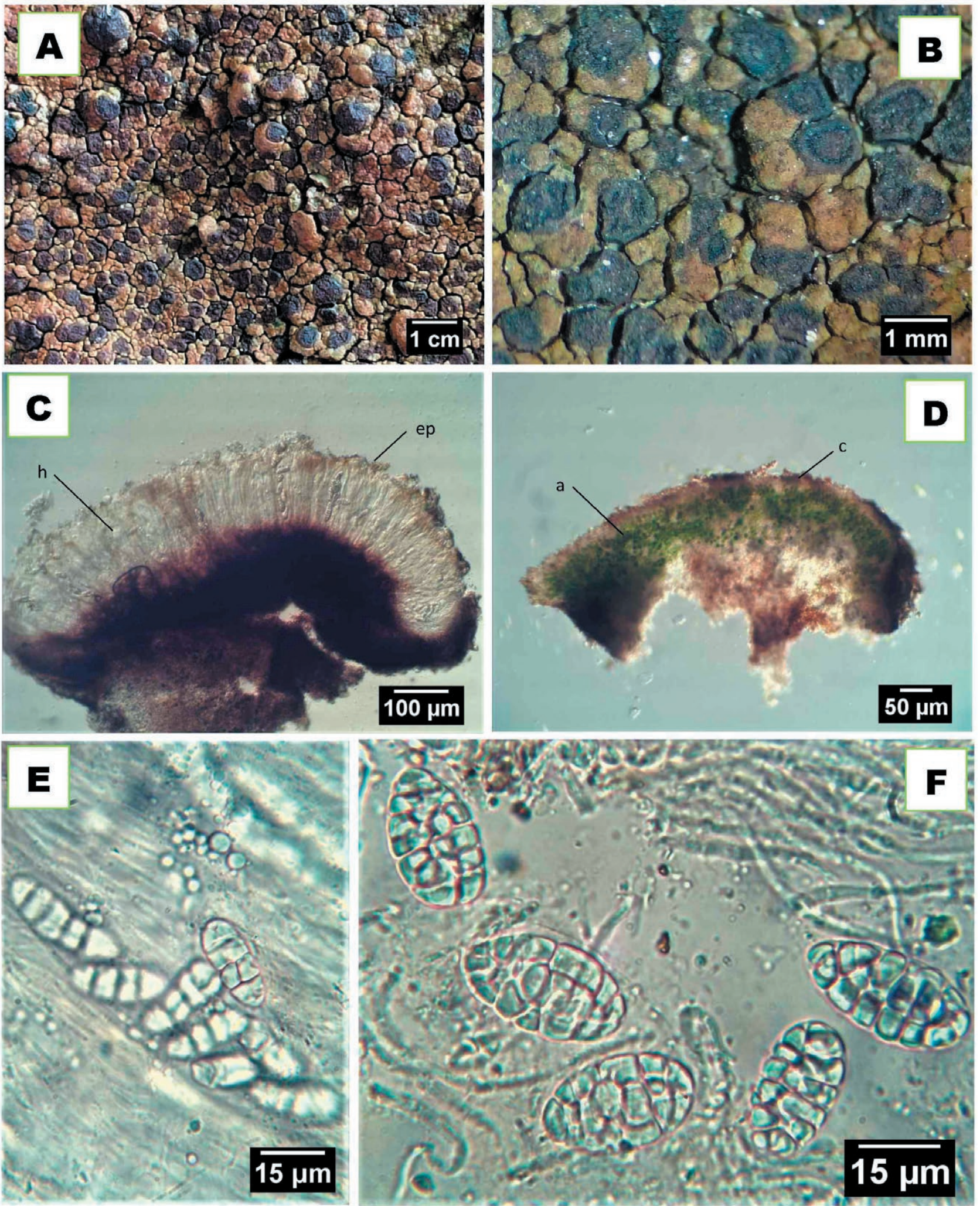

Figure 3. (A-F): Rhizocarpon lavatum. A: showing crustose areolate thallus; B: Apothecia; C: Cross section of an apothecium (h: hymenium; ep: epihymenium); D: Cross section of thallus (c: cortex; a: algal layer); E: Eight-spored ascus; F: Ascospores. 
ter, $R$. reductum is distinct from $R$. lavatum in having more areoles, a thinner apothecial margin, and a taller hymenium (Ihlen 2004). Another similar species, $R$. sublavatum, but it can be separated from $R$. lavatum, by its darker thallus, usually with more areoles, smaller apothecia with a much thinner margin (Ihlen 2004). This study adds $R$. lavatum as a new record to the lichen biota of Pakistan.

Rhizocarpon petraeum (Wulfen) A.Massal., Ric. auton. lich. crost. (Verona): 102. 1852 (Figure 4)

Thallus: crustose, epilithic, areolate, $3-5 \mathrm{~cm}$ across, dull, effuse. Areoles: smooth, epruinose to slightly pruinose, polygonal to irregular, $0.2-1.2 \mathrm{~mm}$ wide, $0.2-0.6$ $\mathrm{mm}$ thick, plane to weakly convex, discrete to rarely contiguous, replicating by division, thin towards thallus margins. Colour: dark grey when dry, no change when wet. Prothallus: absent. Cortex: two layered, upper layer dark brown, lower layer hyaline, paraplectenchymatous, 30-45 $\mu \mathrm{m}$ thick, cells isodiametric, 15-25 $\mu \mathrm{m}$ in diameter. Medulla: hyphae white, 3-4 $\mu \mathrm{m}$ wide; Algal layer: 60-95 $\mu \mathrm{m}$ thick, continuous, photobiont chlorococcoid, cells globose $11-15 \mu \mathrm{m}$.

Apothecia: innate, frequent, Disc: black, epruinose to slightly pruinose, smooth, somewhat shiny, fissured, mostly flat to weakly convex when old, often irregular to rounded, up to $0.6 \mathrm{~mm}$ in diameter. Margins: indistinct, thin. Exciple: dark brown at rim, inside hyaline. Paraphyses: hyaline, septate, branched, anastomosing, apical cells swollen, 2-3 $\mu \mathrm{m}$ wide. Epihymenium: dark brown, 10-25 $\mu \mathrm{m}$ tall. Hymenium: hyaline, 120-160 $\mu \mathrm{m}$ tall. Hypothecium: dark brown, 35-87 $\mu \mathrm{m}$ tall. Asci: hyaline, 8-spored, Rhizocarpon-type, 90-115 $\mu \mathrm{m} \times 20-35 \mu \mathrm{m}$. Ascospores: narrowly ellipsoid to ellipsoid, sometimes slightly ovoid, halonate, hyaline, becoming dark when over mature, eumuriform, 8-15 cells in optical view, 20-28 $\mu \mathrm{m} \times 8-12 \mu \mathrm{m}$.

Chemistry: $\mathrm{K}+$ (yellowish), C-; Secondary metabolite Stictic acid is reported according to literature (Ihlen 2004), not examined in the present material.

\section{Material Examined}

PAKISTAN. Azad Jammu \& Kashmir: Neelam Valley; Kel, 34 ${ }^{\circ} 50^{\prime} \mathrm{N}, 74^{\circ} 22^{\prime} \mathrm{E}$; $2,097 \mathrm{~m}$ a.s.l.; moist temperate forest, on rock; July 12, 2019, A.N. Khalid \& K. Habib, (KL-02), (LAH36712).

\section{Substrate and Ecology}

It was found in temperate climate at an altitude of 2,097 m.a.s.l., growing on base-rich rocks. The mean maximum and minimum temperature of the area is $28^{\circ} \mathrm{C}$ and $-2^{\circ} \mathrm{C}$, respectively, and receive an average annual rainfall of $749 \mathrm{~mm}$. The dominant tree species around were Cedrus deodara (Roxb. ex Lambert) G.Don, Pinus wallichiana A.B. Jacks., Picea smithiana Boiss., Abies pindrow Royle.

\section{Distribution}

The species been reported from Europe (Czech Republic, Estonia, France, Germany, Netherland, Norway, Spain, Sweden, UK, Poland) (Ihlen 2004; Fletcher et al. 2009; Golubkov and Matwiejuk 2009), North America (Canada, US) (https://www.gbif.org/), Australia and Asia (Zhao et al. 2013).

\section{Comments}

In our phylogenetic analysis, R. petraeum and $R$. reductum were found to be strongly supported sister taxa (Figure 5). Morphologically, R. petraeum is also very close to $R$. reductum, as both contain stictic acid and usually have the same insoluble lichen pigments in the ascomata, but $R$. petraeum is distinct in having broader apothecia, and larger ascospores containing more cells.

There were two nucleotide differences found in comparison to the sequence of $R$. petraeum (HQ605942) reported from Turkey. This study reports it as a new record to the lichen biota of Pakistan.

\section{COMPARATIVE ANALYSIS AND CONCLUSIONS}

Our study on four Rhizocarpon species (Table 1) revealed some deviations in the areole size, presence or absence of pruina, height and pigmentation of hymenium and number of cells per ascospore) with in the same taxa published descriptions (Ihlen 2004; Wang et al. 2015).

Rhizocarpon lavatum shows great morphological variation having a wide ecological amplitude (Ihlen 2004) The areole size, pruinose disc of apothecia and lesser number of cells per ascospore of the Pakistani material were found to be in disagreement with the published descriptions (Ihlen 2004; Wang et al. 2015). The areole size was a big difference found between Chinese and Pakistani R. lavatum i.e., $0.4-1.2 \mathrm{~mm}$ (vs. 0.2$0.4 \mathrm{~mm}$ ). The height and pigmentation of hymenium in Pakistani material was almost identical to Chinese specimen as compared to Nordic collection in which the height of hymenium was larger (Table 1).

In Pakistani $R$. petraeum we found thickness of areoles, presence and absence of pruina, height and pigmentation of hymenium and number of cells per ascospore in disagreement with the published descrip- 

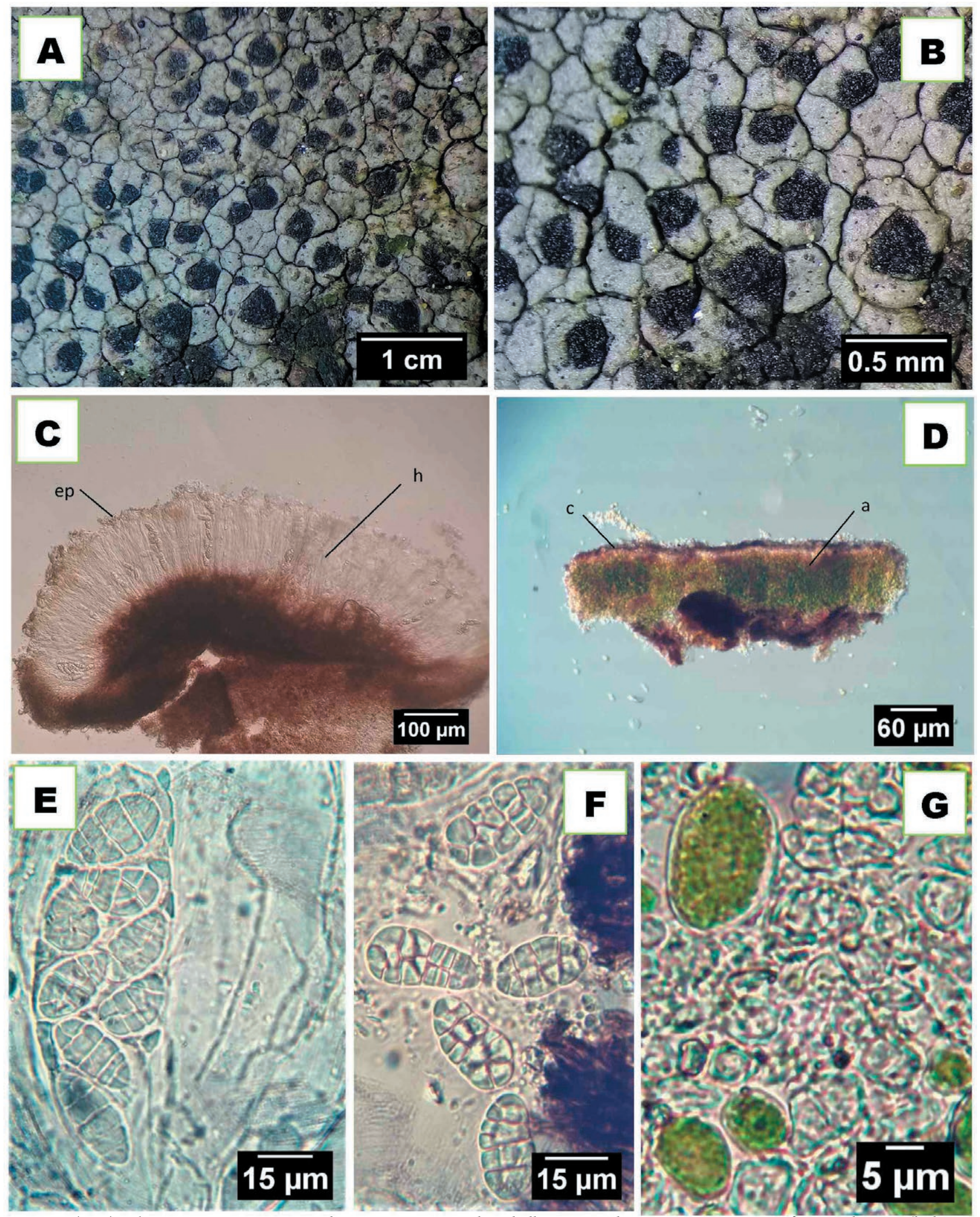

Figure 4. (A-G): Rhizocarpon petraeum. A: showing crustose areolate thallus; B: Apothecia; C: Cross section of an apothecium (h: hymenium; ep: epihymenium); D: Cross section of thallus (c: cortex; a: algal layer); E: Eight-spored ascus; F: Ascospores; G: Chlorococcoid photobiont. 


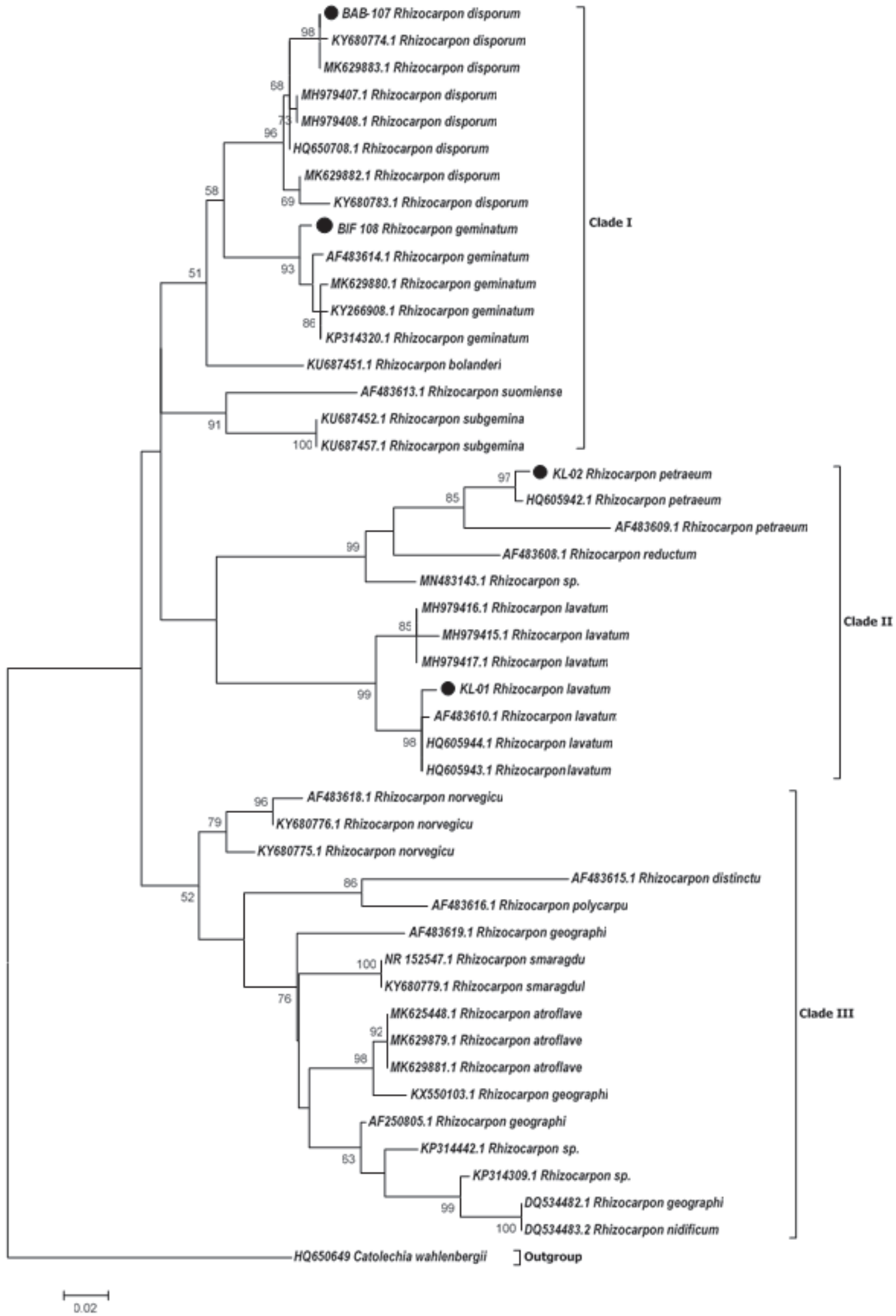

Figure. 5 ITS-based phylogenetic analysis of Rhizocarpon species inferred by using Maximum Likelihood method based on Tamura 3 parameter model. The sequences generated from Pakistan are marked with $\bullet$ 
Table 1. A brief comparison of morpho-anatomical heterogeneity of Pakistani Rhizocarpon species with different countries.

\begin{tabular}{|c|c|c|c|c|c|c|c|c|c|c|c|}
\hline \multirow{2}{*}{$\begin{array}{l}\text { Species/ } \\
\text { Characters }\end{array}$} & \multicolumn{2}{|c|}{ R. disporum } & \multicolumn{3}{|c|}{ R. geminatum } & \multicolumn{3}{|c|}{ R. lavatum } & \multicolumn{3}{|c|}{ R. petraeum } \\
\hline & (Pakistan) & $\begin{array}{c}\text { (North } \\
\text { America) }\end{array}$ & (Pakistan) & (Australia) & $\begin{array}{l}\text { (North } \\
\text { America) }\end{array}$ & (Pakistan) & $\begin{array}{l}\text { (Nordic } \\
\text { countries }\end{array}$ & (China) & (Pakistan) & $\begin{array}{l}\text { (Nordic } \\
\text { countries) }\end{array}$ & (China) \\
\hline Thallus colour & $\begin{array}{l}\text { blackish } \\
\text { brown to } \\
\text { black }\end{array}$ & $\begin{array}{l}\text { grey to grey } \\
\text { brown }\end{array}$ & $\begin{array}{l}\text { dark brown } \\
\text { to black }\end{array}$ & $\begin{array}{l}\text { medium to } \\
\text { dark grey }\end{array}$ & $\begin{array}{l}\text { grey to grey } \\
\text { brown }\end{array}$ & $\begin{array}{l}\text { rusty } \\
\text { brown to } \\
\text { pale } \\
\text { reddish } \\
\text { brown }\end{array}$ & $\begin{array}{l}\text { grey to } \\
\text { brown or } \\
\text { rust } \\
\text { brown }\end{array}$ & $\begin{array}{l}\text { greyish } \\
\text { white or } \\
\text { grey } \\
\text { brown }\end{array}$ & dark grey & $\begin{array}{l}\text { grey to } \\
\text { brown }\end{array}$ & $\begin{array}{l}\text { grey to } \\
\text { brown }\end{array}$ \\
\hline $\begin{array}{c}\text { Areole size } \\
(\mathrm{mm})\end{array}$ & $0.3-1 \mathrm{~mm}$ & same & $0.2-1 \mathrm{~mm}$ & same & same & $0.4-1.2$ & --- & $0.2-0.4$ & $0.2-1.2$ & --- & --- \\
\hline $\begin{array}{c}\text { Apothecial disc } \\
\text { (presence/ absence } \\
\text { of pruina) }\end{array}$ & $-\cdots$ & ----- & pruinose & --- & epruinose & pruinose & $\begin{array}{l}\text { epruinos } \\
\mathrm{c}\end{array}$ & $\begin{array}{c}\text { epruinos } \\
\mathrm{c}\end{array}$ & $\begin{array}{l}\text { Slightly } \\
\text { pruinose }\end{array}$ & epruinose & epruinose \\
\hline $\begin{array}{l}\text { Hymenium } \\
\text { (hcight) \& } \\
\text { Pigmentation }\end{array}$ & $\begin{array}{c}80-125 \\
\mu \mathrm{m} ' \\
\text { hyaline }\end{array}$ & same & $\begin{array}{c}130-200 \\
\mu \mathrm{m}, \\
\text { hyaline }\end{array}$ & --- & $\begin{array}{c}100-140 \\
\mu \mathrm{m}, \\
\text { hyaline }\end{array}$ & $\begin{array}{c}130-155 \\
\mu \mathrm{m}, \\
\text { hyaline }\end{array}$ & $\begin{array}{c}135-260 \\
\mu \mathrm{m}, \\
\text { Hyaline } \\
\text { to light } \\
\text { Atra- } \\
\text { brown or } \\
\text { Macroca } \\
\text { rpa - } \\
\text { green }\end{array}$ & $\begin{array}{c}85-150 \\
\mu \mathrm{m}, \\
\text { hyaline }\end{array}$ & $\begin{array}{c}120-160 \\
\mu \mathrm{m}, \\
\text { hyaline }\end{array}$ & $\begin{array}{c}162-240 \\
\mu \mathrm{m}, \\
\text { Hyaline to } \\
\text { light Atra- } \\
\text { brown or } \\
\text { Macrocarp } \\
\text { a -green }\end{array}$ & $\begin{array}{c}150-200 \\
\mu \mathrm{m}, \\
\text { hyaline }\end{array}$ \\
\hline Asci & - & ---- & 2-spored & 2-4-spored & 2-spored & 8-spored & 8-spored & 8 -spored & 8-spored & 8-spored & 8 -spored \\
\hline $\begin{array}{c}\text { Ascopores/ } \\
\text { (cells in optical } \\
\text { view) }\end{array}$ & ---- & -.-- & muriform & same & same & $8-17$ & $9-28$ & $15-24$ & $8-15$ & $11-30$ & $12-21$ \\
\hline References & $\begin{array}{l}\text { Reported } \\
\text { in this } \\
\text { paper }\end{array}$ & $\begin{array}{l}\text { Nash et al. } \\
2004\end{array}$ & $\begin{array}{l}\text { Reported in } \\
\text { this paper }\end{array}$ & $\begin{array}{l}\text { McCarthy } \\
\text { \& Elix, } \\
2014\end{array}$ & $\begin{array}{l}\text { Nash et al. } \\
2004\end{array}$ & $\begin{array}{l}\text { Reported } \\
\text { in this } \\
\text { paper }\end{array}$ & $\begin{array}{l}\text { Ihlen } \\
2004\end{array}$ & $\begin{array}{l}\text { Wang et } \\
\text { al. } 2015\end{array}$ & $\begin{array}{l}\text { Reported } \\
\text { in this } \\
\text { paper }\end{array}$ & Ihlen 2004 & $\begin{array}{c}\text { Zhao et al } \\
2013\end{array}$ \\
\hline
\end{tabular}

tions of Chinese and Nordic (Ihlen 2004; Zhao et al. 2013). The number of cells per ascospore were less in Pakistani specimen than the Nordic countries and Chinese taxa i.e., 8-15 (vs. 13-21) and (vs. 12-21), respectively. The areole thickness of Pakistani specimen was greater as compared to the Chinese taxon i.e., $0.2-0.6$ $\mathrm{mm}$ (vs. 0.14-0.2 $\mathrm{mm}$ ), while the hymenium pigmentation was largely in agreement with the Chinese description (Zhao et al. 2013), whereas the height and pigmentation of hymenium is not similar to the description of Ihlen (2004).

The description of Pakistani Rhizocarpon disporum is very close to North American samples, which however differs by its colour of thallus, blackish brown to black (vs. grey to grey brown), taller epinecral layer 10-20 $\mu \mathrm{m}$ (vs. $10 \mu \mathrm{m}$ ) and slightly curved ascospores (vs. not curved) (Nash et al. 2004).

\section{REFERENCES}

Abbas A., Mijit H., Tumur A. \& Jinong W. 2001. A checklist of the lichens of Xinjiang, China. Harvard Papers in Botany. 5: 359- 370.

Ahmad S. 1965. A preliminary contribution to the lichenflora of West Pakistan. Biologia (Lahore). 11: 21-47.

Altschul SF, Gish W, Miller W, Myers EW, Lipman DJ. 1990. Basic local alignment search tool. Journal of Molecular Biology. 215(3): 403-410. 
Aptroot A, Iqbal SH. 2012. Annotated checklist of the Lichens of Pakistan, with reports of new records. Herzogia. 25 (2): 211-229.

Clauzade G, Roux C. 1985. Likenoj de Okcidenta Eŭropo. Ilustrita Determinlibro. Bulletin of the Central West Botanical Society, New Series, Special Number. 7: 1-893.

Davydov EA, Yakovchenko LS. 2017. Rhizocarpon smaragdulum, a new monosporic yellow-thalline species and some additional species of the genus Rhizocarpon from the Altai Mountains (Siberia). The Lichenologist. 49(5): 457- 466.

Feuerer T. 1991. Revision of the European species of the lichen genus Rhizocarpon with a non-yellow stock and violet spores. Bibliotheca Lichenologica, 39- 218.

Feuerer T, Timdal E. 2004. Rhizocarpon. In: Nash III T. H., B. D. Ryan, C. Gries and F. Bungartz. (eds), Lichen Flora of the Greater Sonoran Desert Region 2. (Lichens Unlimited, Tempe, Arizona). Pp. 456-466.

Fletcher AO, Gilbert L, Clayden S, Fryday AM. 2009. Rhizocarpon. In: C. W. Smith et al. (eds). The lichens of Great Britain and Ireland. London: British Lichen Society. Pp. 792-808.

Galloway DJ. 2007. Flora of New Zealand Lichens. Revised second edition. Volume 2. (Manaaki Whenua Press, Lincoln).

Gardes M, Bruns TD. 1993. ITS primers with enhanced specificity for basidiomycetes-application to the identification of mycorrhizae and rusts. Molecular Ecology. 2(2): 113- 118.

Golubkov VV, Matwiejuk A. 2009. Some new records of Rhizocarpon from north-eastern Poland and northwestern Belarus. Acta Mycologica. 44(2): 201-210.

Hale ME. 1979. How to Know Lichens ( $2^{\text {nd }}$ edn). William C. Brown Company Publishers.

Hall TA. 2005. Bioedit Version 7.0.4. Department of Microbiology. North Carolina State University.

Ihlen PG., Ekman S. 2002. Outline of phylogeny and character evolution in Rhizocarpon (Rhizocarpaceae, lichenized Ascomycota) based on nuclear ITS and mitochondrial SSU ribosomal DNA sequences. Biological Journal of the Linnean Society. 77(4): 535-546.

Ihlen PG. 2004. Taxonomy of the non-yellow species of Rhizocarpon (Rhizocarpaceae, lichenized Ascomycota) in the Nordic countries, with hyaline and muriform ascospores. Mycological Research. 108(5): 533-570.

Joshi Y, Koh YJ, Hur JS. 2010. Three new records of lichen genus Rhizocarpon from South Korea. Mycobiology. 38(3): 219-221.

Katoh K, Standley DM. 2013. MAFFT multiple sequence alignment software version 7 , improvement in per- formance and usability. Molecular Biology and Evolution. 30: 772-780.

Khan M, Khalid AN, Lumbsch HT. 2018. A new species of Lecidea (Lecanorales, Ascomycota) from Pakistan. Mycokeys. 38: 25.

Kirk PM, Cannon PF, Minter DW, Stalpers JA. 2008. Dictionary of the fungi, 10th edition. Cromwell Press. Townbridge UK. $771 \mathrm{p}$.

Kumar S., Stecher G., Li M., Knyaz C. \& Tamura K. 2018. MEGA X: molecular evolutionary genetics analysis across computing platforms. Molecular Biology and Evolution. 35(6): 1547-1549.

McCarthy P, Elix J. 2014. The lichen genus Rhizocarpon in mainland Australia. Telopea. 16: 195-211.

Moniri MH, Kamyabi S, Fryday AM. 2009. Rhizocarpon saurinum new to Asia, and other reports of Rhizocarpon species from Razavi Khorasan Province, Iran. Mycologica Balcanica. 6: 89-92.

Nash TH, Ryan BD, Gries C, Bungartz F. (eds.) 2004. Lichen Flora of the Greater Sonoran Desert Region. Vol 2. Lichens Unlimited.

Øvstedal DO, Lewis Smith RI. 2001. Lichens of Antarctica and South Georgia: A Guide to their Identification and Ecology. Cambridge University Press.

Poelt J. 1961. Die mitteleuropaischen Arten der Lecideagoniophila-Gruppe. - Ber. Bayerischen Bot Gesell. 34: 82-91. [The Central European species of the Lecidea goniophila group. (Lichenes)].

Sambrook J, Russell DW. 2001. Detection of DNA in agarose gels. Molecular Cloning, A Laboratory Manual, (3rd Ed.) Cold Spring Harbor Laboratory Press. New York 5-14.

Singh KP, Sinha GP. 2010. Indian lichens: an annotated checklist. Kolkata: Botanical Survey of India.

Smith CW, Aptroot A, Coppins BJ, Fletcher A, Gilbert OL, James PW, Wolseley PA. (Eds) 2009. The Lichens of Great Britain and Ireland. Natural History Museum Publications, in association with The British Lichen Society.

Timdal E, Holtan-Hartwig J. 1988. A preliminary key to Rhizocarpon in Scandinavia. Graphis Scripta. 2: 41-54.

Wang WC, Zhao ZT, Zhang LL. 2015. Four Rhizocarpon species new to China. Mycotaxon. 130(3): 883- 891.

White TJ, Bruns T, Lee S, Taylor J. 1990. Amplification and direst sequencing of fungal ribosomal RNA genes for phylogenetics. In: Innis N. Gelfand, D. Sninsky, T. J. White. (Eds) PCR Protocols. - A Guide to the Methods and Applications. Academic Press 315-322.

Zhao ZT, Li C, Zhao X, Zhang LL. 2013. New records of Rhizocarpon from China. Mycotaxon. 125(1): 217- 226. 